\title{
Perkembangan Matematika Dan Pendidikan Matematika Di Indonesia Berdasarkan Filosofi
}

\author{
Jonathan Simanjuntak, S.Pd ${ }^{1}$, Maria Isadora Simangunsong, S.Pd ${ }^{2}$ \\ Tiofanny, S.Pd ${ }^{3}$, Dr. Tutiarny Naibaho, M.Pd ${ }^{4}$ \\ 1,2,3,4 Pascasarja Universitas HKBP Nommensen Medan \\ Jonathansimanjuntak08@gmail.com
}

\begin{abstract}
Abstrak
Penelitian ini bertujuan untuk mengetahui perkembangan pendidikan matematika di Indonesia. metode penelitian yang digunakan adalah Metode deskriptif, dengan menyajikan gambaran, klarifikasi mengenai suatu fenomena dan fakta dalam matematika. Serta studi pustaka (library research). Dengan mengumpulkan beberapa buku, artikel serta pendapat para ahli mengenai perkembangan matematika dan pendidikan matematika yang kemudian dikembangkan dengan berbagai penemuan yang ada. Hasil penelitian menunjukan bahwa perkembangan matematika di dasari oleh filsafat, karena filsafat adalah akar dari segala pengetahuan manusia baik pengetahuan ilmiah maupun pengetahuan non ilmiah. Perkembangan sejarah matematika, matematika Babiliona merujuk pada seluruh matematika yang dikembangkan oleh bangsa Mesopotamia sejak permulaan helenistik. Pada masa itu perkembangan matematika meluas hingga beberapa negara seperti Mesir, Yunani, Arab dan India. Perkembangan pendidikan matematika di Indonesia tidak pernah lepas dari perjalanan sejarah kurikulum dan pentingnya matematika dalam kehidupan maka tidak aneh jika pembelajaran matematika mengalami perkembangan dan disesuaikan dengan kebutuhan zaman. Adapun perkembangan pembelajaran matematika di Indonesia adalah sebagai matematika tradisional, matematika modern, dan matematika masa kini.
\end{abstract}

Kata Kunci : Perkembangan Matematika dan Perkembangan Pendidikan Matematika di Indonesia.

\begin{abstract}
This study aims to determine the development of mathematics education in Indonesia. The research method used is descriptive method, by presenting a description, clarification of a phenomenon and facts in mathematics. As well as library research (library research). By collecting several books, articles and opinions from experts regarding the development of mathematics and mathematics education which are then developed with various existing findings. The results showed that the development of mathematics was based on philosophy, because philosophy is the root of all human knowledge, both scientific knowledge and non-scientific knowledge. The historical development of mathematics, Babiliona mathematics refers to all mathematics developed by the Mesopotamians since the beginning of Hellenism. At that time the development of mathematics expanded to several countries such as Egypt, Greece, Arabia and India. The development of Mathematics Education in Indonesia is never separated from the history of the curriculum. The importance of mathematics in life is not surprising if mathematics learning has developed and adapted to the needs of the times. The development of mathematics learning in Indonesia is as traditional mathematics, modern mathematics, and modern mathematics.
\end{abstract}

Keywords: Mathematics development, Mathematics education development in Indonesia.

\section{Pendahuluan}

Matematika merupakan ilmu universal dalam perkembangan teknologi modern (Suandito, 2017: 13), karena matematika berguna dan banyak memberikan bantuan dalam mempelajari berbagai bidang ilmu yang lain termasuk ilmu alam, teknik, kedokteran/medis, dan ilmu sosial seperti ekonomi, dan psikologi. Sehingga menuntut generasi masa depan untuk wajib mempelajarinya, karena wawasan pendidikan matematika sangat penting bagi siswa dalam memahami karakteristik matematika (Dyahsih \& Ali, 2015: 176). Namun, matematika masih sering di salah artikan oleh kaum pelajar. Selain 
menganggap matematika itu sulit siswa juga sering menganggap bahwa matematika tidak penting atau kurang bermanfaat dalam kehidupan. Menurut Utami dalam Dyahsih \& Ali (2015: 178) menungkapkan bahwa Sebagian siswa belum menyadari akan pentingnya penguasaan matematika sehingga siswa kurang apresiatif terhadap matematika dan dalam mengikuti pembelajaran matematika.

Perkembangan dunia tidak pernah lepas dari peran penting matematika. Sehingga perkembangan dunia selalu mengacu pada perkembangan matematika. Baik perkembangan tekneologi, industri, ekonomi maupun politik, hampir disetiap semua bidang membutuhkan perkembangan metematika (Kamarullah, 2017). Sehingga metematika memiliki hubungan yang istimewa dengan dunia. Oleh karena itu dapat dikatakan bahwa setiap orang khususnya siswa yang berperan sebagai generasi masa depan memerlukan pengetahuan matematika dalam berbagai bentuk ataupun karakteristik sesuai dengan kebutuhannya. Dalam tulisan ini penulis akan membahas tentang perkembangan matematika dan pendidikan matematika. Hal ini untuk mengetahui perkembangan matematika dan pendidikan matematika di dunia dan di Indonesia.

\section{Metode Penelitian}

Penelitian ini mengunakan Metode deskriptif, dengan menyajikan gambaran, klarifikasi mengenai suatu fenomena dan fakta dalam matematika. Serta studi pustaka (library research). Dengan mengumpulkan beberapa buku, artikel serta pendapat para ahli mengenai perkembangan matematika dan pendidikan matematika yang kemudian di kembangkan dengan berbagai penemuan yang ada. Hasil penelitian ini dapat dijadikan sebagai acuan ataupun referensi untuk mencari informasi mengenai perkembangan pendidikan matematika di Indonesia.

\section{Hasil dan Pembahasan}

Perkembangan Matematika dan pendidikan matematika didasari dari filsafat, karena filsafat adalah akar dari segala pengetahuan manusia baik pengetahuan ilmiah maupun pengetahuan non ilmiah. Menurut Parnabakti dan Ulfa (2020: 11) bahwa "Filsafat secara etimologi dapat dilacak pada bahasa Yunani, Phillein yang berarti cinta dan Sophia yang berarti kebijaksanaan". Jadi, filsafat berarti cinta pada kebijaksanaan. Dengan berfilsafat akan diperoleh hakikat segala pengetahuan atau pengetahuan terdalam. Ada empat hal yang mendorong manusia berfilsafat yaitu keraguan, ketakjuban, ketidakpuasan, dan hasrat bertanya (Sukardjono, 2000). Untuk mencapai pengetahuan terdalam maka berfilsafat dilakukan dengan berpikir radikal (sampai ke akar-akarnya), mencari azas/esensi dari setiap realita, memburu kebenaran, mencari kejelasan seluruh realita, serta berpikir rasional, logis, dan sistematis.

Menurut P. Hilton (dalam Prabowo, 2009: 26) bahwa "Matematika lahir dan berkembang karena adanya keinginan manusia untuk mensistematisasikan pengalaman hidupnya, menatanya dan membuatnya mudah dimengerti, supaya dapat meramalkan dan bila memungkinkan mengendalikan peristiwa yang 
akan terjadi pada masa depan". Perkembangan matematika bersifat evolutif, akumulatif dan dikembangkan serta disumbang oleh berbagai bangsa di seluruh dunia. Seringkali, perkembangan matematika pada suatu bangsa akan menemui keruntuhan, tetapi sebelum benar-benar runtuh, telah ada bangsa lain yang siap untuk meneruskan perkembangannya. Hal ini menunjukkan bahwa perkembangan matematika terjadi secara kontinu dan tersusun dari kepingan-kepingan yang dihimpun oleh banyak bangsa dan kebudayaan selama berabad-abad. Esensi dari filsafat matematika adalah sejumlah usaha untuk melakukan rekonstruksi (penyusunan kembali atau penulisan ulang) terhadap sejumlah pengetahuan matematika yang tercerai-berai selama bertahun-tahun yang diberikan dalam aturan atau urutan tertentu. Jadi filsafat adalah fungsi dari waktu, dan fisafat dapat menjadi ketinggalan jaman atau harus berbenah dan berubah sejalan dengan bertambahnya pengalaman dan pengetahuan baru. Dengan kata lain, perlu adanya sebuah sistem, dan itu adalah filsafat matematika, supaya pengetahuan matematis menempati posisi yang secara sistematis mempunyai kebenaran yang terjaga. Agar matematika menjadi satu, utuh dan terpadu maka keberadaan filsafat matematika menjadi perlu dan mutlak harus ada. Harapan besar dibebankan kepada para filosof dan matematikawan untuk menjadikan filsafat matematika sebagai penyusun, penghimpun, dan penertib ilmu matematika yang telah terpecah menjadi kepingan-kepingan selama berabad-abad, akibat banyaknya kontradiksi yang mewarnai perkembangan matematika dan meminta untuk diselesaikan.

Filsafat matematika dikembangkan melalui isu-isu eksternal seperti sejarah, asal-usul, dan praktek matematika dengan isu-isu internal seperti epistemologi dan ontologi. Metode yang digunakan untuk melakukan klasifikasi aliran-aliran dalam filsafat matematika salah satunya menggunakan kriteria kecukupan filsafat matematika (Ernest, 1991) yaitu: (1) pengetahuan matematika: sifat, justifikasi, dan asal-usul pengetahuan, (2) obyek matematika: ruang lingkup dan asal-usul obyek matematika, (3) aplikasi matematika: efektifitas matematika dalam mengembangkan sains, teknologi dan aplikasi lainnya, dan (4) praktek matematika: aktifitas matematikawan, dulu dan sekarang. Kriteria tersebut saat ini melahirkan beberapa aliran filsafat matematika, yaitu Platonisme, Absolutisme dan Falibilisme. Platonisme lebih menekankan pada tidak adanya landasan-landasan untuk merekonstruksi dan menyelamatkan matematika, sementara itu, absolutisme lebih menekankan pada tidak adanya kesalahan pada matematika, sedangkan falibilisme menekankan pada kemungkinan matematika untuk direvisi terus-menerus.

\subsection{Perkembangan Matematika Di Dunia}

Matematika digunakan di seluruh dunia sebagai alat penting berbagai bidang termasuk ilmu alam,teknik, kedokteran / medis, dan ilmu social seperti ekonomi dan psikologi. Perkembangan sejarah matematika, matematika babiliona merujuk pada seluruh matematika yang dikembangkan oleh bangsa mesopotamia sejak permulaan helenistik. Dinamai "matematika babiliona" karena peran utama kawasan babiliona sebagai tempat untuk belajar. Pada zaman perdaban helenistik matematika babiliona 
Volume 02, No.02, Mei 2021

berpadu dengan matematika yunani dan mesir untuk membangkitkan matematika yunani. Matematika babiliona ditulis dalam 400 lempengan tanah liat yang berisi topik-topik pecahan aljabar,invers,perkalian,dan bilangan prima kembar, lempengan itu juga meliputi tabel perkalian dan metode penyelesaian persamaan linier dan persamaan kuadrat. Matematika babiliona menggunakan system decimal dan $=3,125$, merupakan penemu kalkulator pertama kali, mengenal geometri sebagai basis perhitungan astronomi.

Matematika Mesir yang paling panjang adalah lembaran rhind (lembaran ahmes), diperkirakan berasal dari tahun 1650 SM tetapi mungkin lembaran itu adalah salinan dari dokumen yang lebih tua dari kerajaan tengah yaitu tahun 2000-1800SM . Lembaran itu adalah manual instruksi bagi pelajar aritmatika dan geometri. Selain memberikan rumus-rumus luas dan cara-cara perkalian,pembagian dan pengerjaan pecahan, lembaran itu juga menjadi bukti bagi pengetahuan matematika lainnya,termasuk bilangan komposit dan prima,rata-rata aritmatika, geometrid an-harmonic dan pemahaman sederhana saringan eratosthenes dan teori bilangan (yaitu,bilangan 6). Lembaran itu juga berisi cara menyelesaikan persamaan linier order satu juga barisan aritmatika dan geometri serta tiga unsure geomteri mengenai geometri analitik : pertama cara memperoleh hampiran yang akurat dari satu persen,kedua upaya kuno penguadratan libgkaran dan ketiga,penggunaan terdini cotangent. Nasakah matematika mesir penting lainnya adalah lembaran moskwa,juga dari zaman kerajaan pertengahan (1890 SM). Naskah ini berisikan soal kata atau soal cerita,yang barangkali ditujukan sebagai hiburan serta lembaran berlin (1300 SM) menunjukka bahwa bangsa mesir kuno dapat menyelsaikan persamaan aljabar orde dua.

Matematika Yunani merujuk pada matematika yang ditulis didalam ahasa yanani antara tahun 600SM sampai 300SM. Matematika Yunani diayakini dimulakan oleh thales dari miletus (624 sampai 546 SM) selain tokoh-tokoh tersebut ada beberapa tokoh lain yang berperan dalam perkembangan matematika Yunani diantaranya Pythagoras membuktikan Pythagoras secara matematis (terbaik), pencetus awal konsep nol adalah Al khwarizmi, Archimedes mencetuskan nama parabola yang artinya bagian sudut kanan kerucut, Hipassus penemu bilangan irrasional, Diophantus penemu aritmatika (pembahasan teoriteori bilangan yang isinya merupakan pengembangan aljabar yang dilakukan dengan membuat sebuah persamaan.)

Matematika India, Matematika Vedanta dimulakan di India sejak Zaman Besi. Shatapatha Brahmana (kira-kira abad ke-9 SM), menghampiri nilai $\pi$, dan Sulba Sutras (kira-kira 800-500 SM) yang merupakan tulisan-tulisan geometri yang menggunakan bilangan irasional, bilangan prima, aturan tiga dan akar kubik; menghitung akar kuadrat dari 2 sampai sebagian dari seratus ribuan; memberikan metode konstruksi lingkaran yang luasnya menghampiri persegi yang diberikan, menyelesaikan persamaan linear dan kuadrat; mengembangkan tripel Pythagoras secara aljabar, dan memberikan pernyataan dan bukti numerik untuk teorema Pythagoras. 
Matematika Arab, Pada abad ke-sembilan hingga abad tiga belas merupakan zaman puncak masa emasnyaperkembangan matematika bangsa bangsa Arab. Selang perioda tersebut semua ilmu pengetahuan kuno baik dari Yunani dan negri negri lainnya telah diterjemahkan dan di filing di Arab. Sehingga Arab bisa menjadi pustaka ilmu pengetahuan kala itu. Peran bangsa arab jika di telaah dalam perkembangan sejarah matematika tidak hanya sebagai compiler dan penyebar ilmu kepada bangsa lain. Bangsa arab bahkan berperan serta dalam mengkontribusikan beberapa penemuan ilmu pengetahuan tersendiri. Selain hanya mengalih bahasakan serta memberi penjelasan terhadap matematika Yunani, ahli matematika arab juga memiliki karya karya otentik original mereka sendiri. Kemudian pada pertengahan abad ke- 20 di Amerika Serikat terdapat proyek pengajaran matematika yang dipimpin oleh Beberman tahun 1952, yaitu UICSM (The University of Illinois Committee on School Matematics) yang menekankan pada pengertian dan penemuan. Karena proyek ini merupakan cikal bakal matematika modern maka Beberman sebagai pemimpin proyek tersebut disebut sebagai Bapak Matematika Modern.Untuk memajukan teknologinya maka dilakukan proyek perbaikan pendidikan terutama pengajaran matematika. Salah satunya dibuat sebuah gerakan matematika modern yang merupakan kelanjutan dari proyek UICSM yaitu proyek SMSG (School Mathematics Study Group) yang dipimpin oleh Dr. E. Begle tahun 1958, yang hasilnya mampu memberi perubahan besar bukan saja di Amerika tapi juga bagi pengajaran matematika di seluruh dunia.

Berdasarkan peristiwa di atas dengan mengetahui akan peran penting dari matematika, pemerintah setiap negara mengajukan bahwa matematika harus diajarkan kepada setiap peserta didik dan menjadi pembelajaran wajib dalam dunia pendidikan.

\subsection{Perkembangan Pendidikan Matematika Di Indonesia}

Dalam perjalanan sejarah sejak tahun 1945, kurikulum pendidikan nasional telah mengalami perubahan, yaitu pada tahun 1947, 1952, 1964, 1968, 1975, 1984, 1994, 2004, 2006 dan 2013. Perubahan tersebut merupakan konsekuensi logis dari terjadinya perubahan sistem politik, sosial budaya, ekonomi, dan iptek dalam masyarakat berbangsa dan bernegara. Sebab, kurikulum sebagai seperangkat rencana pendidikan perlu dikembangkan secara dinamis sesuai dengan tuntutan dan perubahan yang terjadi di masyarakat. Semua kurikulum nasional dirancang berdasarkan landasan yang sama, yaitu Pancasila dan UUD 1945, perbedaanya pada penekanan pokok dari tujuan pendidikan serta pendekatan dalam merealisasikannya.

Perkembangan pembelajaran matematika di Indonesia tidak lepas dari perjalan sejarah kurikulum di atas, dimulai dengan matematika tradisional (sebelum tahun 1975), pembelajaran matematika modern (Kurikulum 1975), pembelajaran matematika masa kini (Kurikulum 1984), pembelajaran matematika pada Kurikulum 1994, pembelajaran matematika pada Kurikulum Berbasis Kompetensi (Kurikulum 2004), pembelajaran matematika pada Kurikulum Tingkat Satuan Pendidikan (Kurikulum 2006) serta Kurikulum 21013. 
Pembelajaran matematika masa kini adalah pembelajaran era 1980-an. Hal ini merupakan gerakan revolusi matematika kedua, walaupun tidak sedahsyat pada revolusi matematika pertama atau matematika modern. Revolusi ini diawali oleh kekhawatiran negara maju yang akan disusul oleh negara-negara terbelakang saat itu, seperti Jerman barat, Jepang, Korea, dan Taiwan. Pembelajaran matematika ditandai oleh beberapa hal yaitu adanya kemajuan teknologi muthakir seperti kalkulator dan komputer. Perkembangan matematika di luar negeri tersebut berpengaruh terhadap matematika dalam negeri. Di dalam negeri, tahun 1984 pemerintah melaunching kurikulum baru, yaitu kurikulum tahun 1984. Alasan dalam menerapkan kurikulum baru tersebut antara lain, adanya sarat materi, perbedaan kemajuan.

Pendidikan antar daerah dari segi teknologi, adanya perbedaan kesenjangan antara program kurikulum di satu pihak dan pelaksana sekolah serta kebutuhan lapangan dipihak lain, belum sesuainya materi kurikulum dengan tarap kemampuan anak didik. Dan, CBSA (cara belajar siswa aktif) menjadi karakter yang begitu melekat erat dalam kurikulum tersebut.

Melihat pentingnya matematika dalam kehidupan maka pembelajaran matematika mengalami perkembangan dan disesuaikan dengan kebutuhan zaman. Adapun perkembangan pembelajaran matematika di Indonesia menurut Alhaddad (2015: 14-16) adalah sebagai berikut.

1) Matematika Tradisional

Setelah Indonesia terlepas dari penjajahan kolonial, pemerintah berbenah diri menyusun program pendidikan. Matematika diletakkan sebagai salah satu mata pelajaran wajib. Saat itu pembelajaran matematika lebih ditekankan pada ilmu hitung dan cara berhitung. Urutan-urutan materi seolah-olah telah menjadi konsensus masyarakat. Karena seolah-olah sudah menjadi konsensus maka ketika urutan dirubah sedikit saja protes dan penentangan dari masyarakat begitu kuat. Untuk pertama kali yang diperkenalkan kepada siswa adalah bilangan asli dan membilang, kemudian penjumlahan dengan jumlah kurang dari sepuluh, pengurangan yang selisihnya positif dan lain sebagainya. Selain itu pembelajaran matematika tradisional di Indonesia juga mempunyai ciri yang serupa dengan pembelajaran tradisional pada umumnya, seperti materinya materi lama, lebih mengutamakan hafalan daripada pengertian, menekankan kepada keterampilan berhitung, menekankan kepada bagaimana sesuatu itu dihitung daripada kepada mengapa sesuatu itu dihitung demikian, lebih mengutamakan kepada melatih otak daripada kegunaannya, bahasa/ istilah/ symbol yang dipergunakan tidak jelas (ambiguous), urutan operasi harus diterima tanpa alasan, dan lain lain (Ruseffendi, 1990a:70).

2) Matematika Modern

Pembelajaran matematika modern resminya dimulai setelah adanya kurikulum 1975. Model pembelajaran matematika modern ini muncul karena adanya kemajuan teknologi, di Amerika Serikat perasaan adanya kekurangan orang-orang yang mampu menangani senjata, rudal dan roket sangat sedikit, mendorong munculnya pembaharuan pembelajaran matematika. Selain itu penemuanpenemuan teori belajar mengajar oleh J. Piaget, W Brownell, J.P Guilford, J.S Bruner, Z.P Dienes, 
D.Ausubel, R.M Gagne dan lain-lain semakin memperkuat arus perubahan model pembelajaran matematika.

Brownell mengemukakan bahwa belajar matematika harus merupakan belajar bermakna dan berpengertian. Teori ini sesuai dengan teori Gestalt yang muncul sekitar tahun 1930, di mana Gestalt menengaskan bahwa latihan hafal atau yang sering disebut drill adalah sangat penting dalam pembelajaran namun diterapkan setalah tertanam pengertian pada siswa. Dua hal tersebut di atas mempengaruhi perkembangan pembelajaran matematika di Indonesia, berbagai kelemahan pembelajaran matematika tradisional seolah nampak jelas, pembelajaran kurang menekankan pada pengertian, kurang adanya kontinuitas, kurang merangsang anak untuk ingin tahu, dan lain sebagainya. Ditambah lagi masyarakat dihadapkan pada kemajuan teknologi. Akhirnya Pemerintah merancang program pembelajaran yang dapat menutupi kelemahan- kelemahan tersebut, munculah kurikulum 1975.

3) Pembelajaran Matematika Masa Kini

Pembelajaran matematika masa kini adalah pembelajaran era 1980-an. Hal ini merupakan gerakan revolusi matematika kedua, walaupun tidak sedahsyat pada revolusi matematika pertama atau matematika modern. Revolusi ini diawali oleh kekhawatiran negara maju yang akan disusul oleh negara-negara terbelakang saat itu, seperti Jerman barat, Jepang, Korea, dan Taiwan.

Pembelajaran matematika ditandai oleh beberapa hal yaitu adanya kemajuan teknologi muthakir seperti kalkulator dan komputer. Perkembangan matematika di luar negeri tersebut berpengaruh terhadap matematika dalam negeri. Di dalam negeri, tahun 1984 pemerintah melaunching kurikulum baru, yaitu kurikulum tahun 1984. Alasan dalam menerapkan kurikulum baru tersebut antara lain, adanya sarat materi, perbedaan kemajuan pendidikan antar daerah dari segi teknologi, adanya perbedaan kesenjangan antara program kurikulum di satu pihak dan pelaksana sekolah serta kebutuhan lapangan dipihak lain, belum sesuainya materi kurikulum dengan tarap kemampuan anak didik. Dan, CBSA (cara belajar siswa aktif) menjadi karakter yang begitu melekat erat dalam kurikulum tersebut.

\section{Kesimpulan}

Berdasarkan uraian diatas mengenai perkembangan matematika dan pendidikan matematika, maka dapat disimpulkan bahwa :

1) Perkembangan Matematika di dasari oleh filsafat, karena filsafat adalah akar dari segala pengetahuan manusia baik pengetahuan ilmiah maupun pengetahuan non ilmiah.

2) Perkembangan sejarah matematika, matematika babiliona merujuk pada seluruh matematika yang dikembangkan oleh bangsa mesopotamia sejak permulaan helenistik. Pada masa itu perkembangan matematika meluas hingga beberapa negara seperti Mesir, Yunani, Arab dan India.

3) Perkembangan Pendidikan Matematika di Indonesia tidak pernah tidak lepas dari perjalan sejarah kurikulum, Pentingnya matematika dalam kehidupan maka tidak aneh jika pembelajaran matematika mengalami perkembangan dan disesuaikan dengan kebutuhan zaman. Adapun 
perkembangan pembelajaran matematika di Indonesia adalah sebagai matematika tradisional, matematika modern, dan matematika masa kini.

\section{Referensi}

Alhaddad, I. (2015). Perkembangan Pembelajaran Matematika Masa Kini. Jurnal: Delta-pi. 4 (1), 13 26. https://core.ac.uk/download/pdf/267889459.pdf. (online, diakses 15 Des 2020).

Dyahsih, A. S. \& Ali, M. (2015). Keefektifan Experiential Learning Pembelajaran Matematika MTs Materi Bangun Ruang Sisi Datar. Jurnal Riset Pendidikan Matematika. 2 (2), 175-185. http://journal.uny.ac.id/index.php/jrpm/index. (Online, diakses 15 Desember 2020).

Ernest, P. (1991). The Philosophy of Mathematics Education. Routledge Falme Kamarullah. (2017). Pendidikan Matematika DI Sekolah Kita. Al Khawarizmi: Jurnal Pendidikan dan Pembelajaran Matematika. 1 (1), 21-32. http://dx.doi.org/10.22373/jppm.v1i1.1729 (Online, diakses 15 Desember 2020).

Parnabhakti, L. \& Ulfa, M. (2020). Perkembangan Matematika Dalam Filsafat Dan Aliran Formalisme Yang Terkandung Dalam Filsafat Matematika. Jurnal Ilmiah Matematika $\begin{array}{llll}\text { Realistik. } & 1 & \text { 11-14. }\end{array}$ http://jim.teknokrat.ac.id/index.php/pendidikanmatematika/index (Online, diakses 15 Desember 2020).

Prabowo, A. (2009). Aliran-aliran Filsafat dalam Matematika. Jurnal Ilmiah Matematika dan Pendidikan Matematika. 1 (2), 25-45. https://doi.org/10.20884/1.jmp.2009.1.2.2979. (Online, diakses 15 Desember 2020).

Ruseffendi. 1990. Pengajaran Matematika Modern dan Masa Kini. Bandung: Tarsito

Sudianto, B. (2017). Bukti Informal dalam Pembelajaran Matematika. Al-Jabar : Jurnal Pendidikan Matematika. $8 \quad$ (1). 13-24. http://ejournal.radenintan.ac.id/index.php/aljabar/article/view/1160/902 (Online, diakses 12 Desember 2020).

Sukardjono. (2000). Filsafat dan Sejarah Matematika. Penerbit: Universitas Terbuka. 